\title{
Prostate Carcinoma by Gene Expression Profile
}

National Cancer Institute

\section{Source}

National Cancer Institute. Prostate Carcinoma by Gene Expression Profile. NCI

Thesaurus. Code C138167.

A header term that includes the following prostate carcinoma subtypes determined by gene expression profiling: luminal A prostate carcinoma, luminal B prostate carcinoma, and basal-like prostate carcinoma. 